\title{
Magnesium layered hydroxide-3-(4-methoxyphenyl) propionate modified single-walled carbon nanotubes as sensor for simultaneous determination of Bisphenol A and Uric Acid
}

\author{
Rahadian Zainul ${ }^{1, *}$, Norhayati Hashim ${ }^{2}$, Siti Nur Akmar Mohd Yazid ${ }^{2}$, Sharifah Norain Mohd Sharif ${ }^{2}$, \\ Mohamad Syahrizal Ahmad ${ }^{2}$, Mohamad Idris Saidin', Suyanta ${ }^{3}$, M.M.C. Sobry² and Illyas Md Isa, ${ }^{2}$, \\ ${ }^{1}$ Department of Chemistry, Faculty of Mathematics and Natural Science, Universitas Negeri Padang, \\ West Sumatera, 25173, Indonesia \\ ${ }^{2}$ Nanotechnology Research Centre, Faculty of Science and Mathematics, Universiti Pendidikan Sultan \\ Idris, 35900 Tanjong Malim, Perak, Malaysia; \\ ${ }^{3}$ Deparment of Chemistry Education, Faculty of Mathematics and Natural Science, Yogyakarta State \\ University, Indonesia \\ *E-mail: rahadianzmsiphd@ fmipa.unp.ac.id; illyas@ fsmt.upsi.edu.my
}

Received: 12 May 2021 / Accepted: 27 June 2021 / Published: 10 August 2021

\begin{abstract}
A facile electrochemical sensor based on single-walled carbon nanotubes/magnesium layered hydroxide3-(4-methoxyphenyl) propionate nanocomposites paste electrode (MWCNT/MLH-MPP) for determination of bisphenol A (BPA) and uric acid (UA) was constructed in this study. According to experiments, several parameters affecting the electroanalytical responses of the prepared electrode were optimised, such as amount of modifier, square wave voltammetry parameters, and $\mathrm{pH}$ effect. Under optimum experimental conditions, electrochemical current of BPA and UA oxidation were linearly proportional to the concentrations from $3.0 \times 10^{-7} \mathrm{M}$ to $1.0 \times 10^{-4} \mathrm{M}$ and $1.0 \times 10^{-7} \mathrm{M}$ to $1.0 \times 10^{-4} \mathrm{M}$ for BPA and UA respectively with the both limit of detection of $5.0 \times 10^{-8} \mathrm{M}$. The small percentage of relative peak currents changes with added some interference indicated that the modified electrode can be used for the determination of BPA and UA in real samples such as baby teether and urine.
\end{abstract}

Keywords: single-walled carbon nanotube; nanocomposite; bisphenol A; uric acid; electrochemical sensor

\section{FULL TEXT}

(C) 2021 The Authors. Published by ESG (www.electrochemsci.org). This article is an open access article distributed under the terms and conditions of the Creative Commons Attribution license (http://creativecommons.org/licenses/by/4.0/). 